\title{
COVID-19 IN PAKISTAN: HOW TO SPARK THE ECONOMIC RECOVERY-ANALYSIS FROM PREVIOUS NATURAL DISASTERS
}

\author{
Usama Anwar a, Abdul Rehman Nawaz a , Hafiz Ghulam Mujaddad a,* \\ a School of Economics, University of the Punjab, Lahore, Pakistan
}

\section{ARTICLE INFO}

\section{Article history}

Received: August 09, 2021

Revised: September 15, 2021

Accepted: September 18, 2021

\section{Keywords}

COVID-19

Natural disasters

Economic crisis

Pakistan

\section{ABSTRACT}

COVID-19 is reshaping the future of the globe by having an unprecedented impact on people's social, political, and economic lives. This pandemic is being characterized by health crisis as well as economic crisis. Pertaining to the negative demand \& supply shocks and the decrease in revenues, profits, and investment due to COVID-19, many business and economic institutions are paying heed to subdue the post-pandemic economic recession. The COVID-19 pandemic crisis also hit the economy of Pakistan rigorously. Due to persistent lockdown and de-escalated economic activities, the country faced a sharp decline in tax revenues, investment, and business growth. Pakistan has faced several economic downturns due to natural disasters: particularly the flood in 2010 and the earthquake in 2005, as they caused the loss of numerous lives, infrastructure, businesses, and irrigation land. The present study reviews the response and effectiveness of government and different institutions in previous natural disasters. This analysis provides policy recommendations to deal with the current crisis. The study concludes that Pakistan failed to get the full output of its recovery plans due to lack of preparedness \& coordination, lack of understanding, insufficient knowledge \& planning, the ineffective role of central management, and other institutional or management issues. It further recommends that Pakistan should act more effectively against natural disasters and restore its previous economic pace by eliminating the gaps in its economic and disaster management policies.

\footnotetext{
*Email: ghulam.eco@pu.edu.pk

https://doi.org/10.52223/jei3032111

(c) The Author(s) 2021.

This is an open access article under the CC BY license (http://creativecommons.org/licenses/by/4.0/).
}

\section{INTRODUCTION}

Sapiens started living in communities about 10,000 years ago (Umer, 2018). The substantial nexus among humankind is perhaps the most crucial factor behind the survival of this specie (Harari, 2014). Long before globalization, pandemics have existed. The term "pandemic" can be defined as an epidemic occurring worldwide or over a very wide area, crossing international boundaries and usually affecting millions of people (Last, 2001). In the past, pandemics have not only caused millions of people to die but also have created major economic losses across the world (James \& Sargent, 2006).

According to available literature, an epidemic that exists over a large geographical area nearly covering a particular region or whole globe and showing explosiveness in transmission can be termed a pandemic (Phin, 2011). Pandemics can be transregional (if spreading to at least two adjacent regions), interregional (if spreading to at least two non-adjacent regions), and global in nature (if spreading to a hemisphere and often worldwide) (Taubenberger \& Morens, 2009). Humankind has suffered several pandemics throughout its history. The modern definition of pandemics includes attack rates, immunity in population, contagiousness, infectiousness, novelty, and severity (Morens et al., 2009). The real difficulty lies in the prediction of how and why these pandemics occur in different countries (Saunders-Hastings \& Krewski, 2016). Spanish flu (1918-1920), Asian flu (1957-1958), Hong Kong flu (19681978), SARS outbreak (2002-2003), and Swine flu (2009-2010) are some famous pandemics in world history.

In 2019, a virus emerged from China, Wuhan, named 'Severe Acute Respiratory Syndrome' or 'Coronavirus-2' (SARS-CoV2) and abbreviated as COVID-19. The causing agent of COVID19 was named SARS-CoV-2. It has a genetic sequence resembling other coronaviruses. Shred of evidence from genetic sequence suggests that the bats are the possible origin of the COVID-19. On March 11, 2020, the World Health Organization declared COVID-19 a pandemic as the patient hit 200,000. The first case of novel coronavirus was reported in Wuhan, China, in December 2019, and the 1st COVID-19 case outside China was reported on January 14,20 , in Thailand (WHO, 2020a). Till the end of this year, millions of cases have been reported worldwide. As reported on November 9, 2020, around 50 million people were infected by COVID-19 (BBC, 2020). Similarly, the numbers of death 
reported due to COVID-19 were around 1.4 million on November 6, 2020 (WHO, 2020b).

On February 12, 2020, the Ministry of National Health of Pakistan presented a "National Action Plan for Preparedness \& Response to Corona Virus Disease (COVID-19)". The purpose of this plan was to recommend measures and take the necessary actions to control the spread of the virus. The first case of COVID-19 in Pakistan was reported on February 26, 2020. The COVID-19 curve became vertical in Pakistan as thousands of pilgrims returned to Pakistan from Iran. The government took effective initial measures at the 'Taftan' border; however, at that time, 8000 pilgrims had already returned to Pakistan (Waris et al., 2020). The government of Pakistan allocated special quarantine zones for infected people, but somehow, the infected people escaped those zones. Owing to lack of facilities in quarantine zones at the 'Taftan' border with Iran, around 2000 pilgrims were shifted to their homes. By March 24, 2020, around 990 cases were reported in Pakistan, and $60 \%$ were these pilgrims (Badshah et al., 2020). On June 14 , 2020 , the highest number of cases were reported in a single day, which was 6825. Anyhow, the COVID's curve became flatter as Pakistan reported the lowest number of cases, in a single day, on August 3, 2020. The situation is becoming worse again as the $2^{\text {nd }}$ COVID-19 wave is on the way. On November 26, 2020, a total of 3113 confirmed cases were reported in Pakistan. The COVID-19 cases are increasing in Pakistan again as the government ended up the lockdown in Jan 2021. It seems that Pakistan has been entered into the 3rd wave of COVID-19. A simple comparison between the number of tests performed and the number of new cases is demonstrated in Figure 1. .

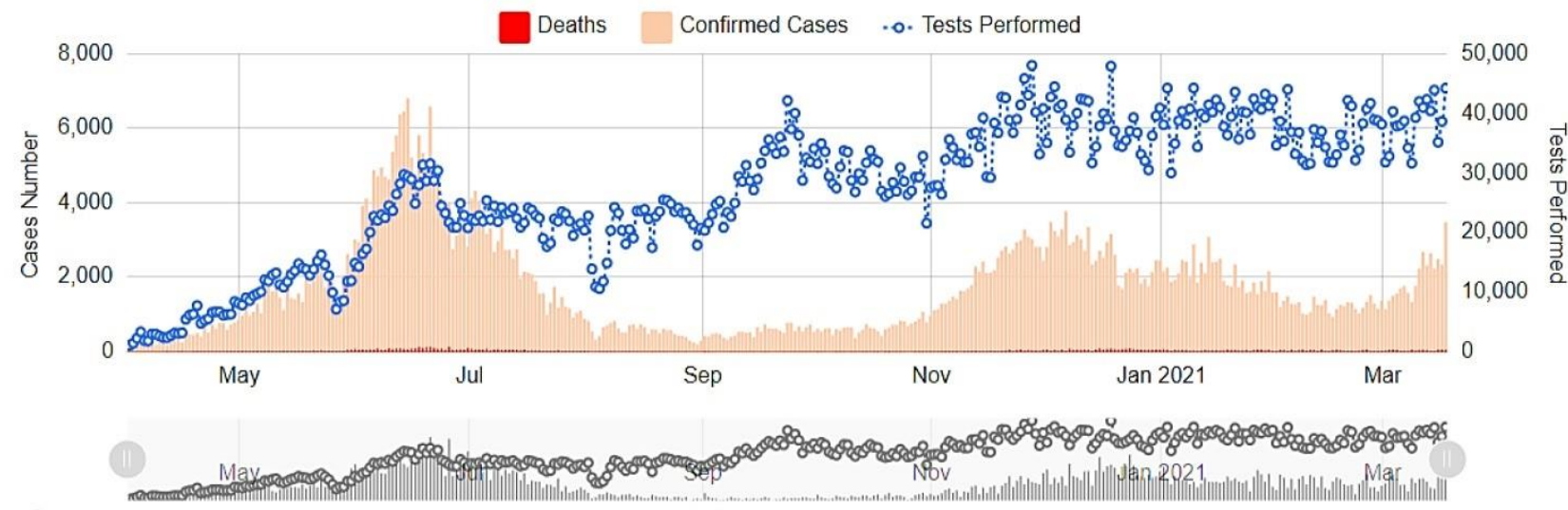

Figure 1. COVID-19 status in Pakistan during May 2019-March 2021.

Source: Ministry of National Health, Government of Pakistan (GOP, 2021).

Unlike other countries, the government of Pakistan was able to contain the virus due to an effective lockdown policy. The government of Pakistan implemented precautionary measures and imposed lockdowns at various levels. But this lockdown affected the economic sector of the country badly. All industrial, domestic/international transport systems, education, and manufacturing sectors halted their operations abruptly (Abid et al., 2020). Similarly, the financial impact of this lockdown is far more than this lethal COVID-19. Most of the countries across the globe suspended their air travel, maintained social distances, and closed their border to minimize the spread of COVID-19 (Thunstrom et al., 2020).

COVID-19 has affected manufacturing, tourism, sports, transport, and all other economic sectors of the world economy. Governments around the world put a nation-wide lockdown in the countries. The global supply chain was mainly disrupted and the global trade declined. Due to the persisting lockdown situation, the distribution of goods within the country was primarily affected. It is estimated that each additional month of lockdown would cost $2.5-3 \%$ of global GDP and there would be a loss of $3-15 \%$ of the world GDP by the end of 2020, depending upon the period of lockdown and normalization of the situation (Fernandes, 2020). COVID-19 had a terrible impact on the world's financial market (Zang et al., 2020). The risk in stock markets increased and shareholders lost their return with each coming day. People were cautious about investing and so the stock markets shed their points day by day. Moreover, ArabRussia oil war has added fuel to the fire; thus, the stock market crashed as the oil prices decreased. The global GDP would fall by $2 \%$, and even economic recession seems inevitable (Maliszewska et al., 2020). Not to speak of developing nations, even the developed economies halted their manufacturing units to cope with the situation. The apparel manufacturing industry declined sharply in Bangladesh, and retailers closed their shops with little turnovers (Sen et al., 2020). USA, China, Japan comprise the major portion of the world GDP, i.e., $24 \%, 16 \%$ and $5 \%$, respectively, and the larger the share is, the bigger the effect will be on world economies (Baldwin \& Di Mauro, 2020). This trade embargo disrupted the global supply chain, and the process further going on from one country to another. Gruszczynski (2020) argues that COVID-19 has not only impacted the world's trade but also changed its patterns structurally.

Pakistan's economy has been shrinking since 2019, before coronavirus has invaded the world economy. According to the Pakistan Bureau of Statistics, around a 1.9\% growth rate was being projected for the fiscal year 2019, but now it has gone negative as the economy is continuously shrinking. All three pillars of the economy, i.e., agriculture, services, and industry are under catastrophe as COVID-19 has hit the economy. International, as well as domestic trade routes are closed that disrupted the local and global supply chain. 
The pandemic outbreak put everything nearly to halt. The economy of Pakistan was already going through a transition due to the balance of payment crisis in 2019, which resulted to seeking out a bailout package from the International Monetary Fund. The negative spillover effects of COVID-19 in the form of disruption in global trade, a decline in FDI, and foreign remittances put great pressure on the external sector of Pakistan. The economy of Pakistan was projected to lose about $4 \%$ of its GDP due to the reduction of trade (Haider, 2020) and the remittances were expected to decline from 9 to $14 \%$ in the FY20 (Iqbal \& Javid, 2020). The unemployment layoffs, poverty, disruption in the supply chain, and negative impacts of COVID19 on education proved to be the biggest challenges for Pakistan (Rasheed et al., 2021). The reduction in tourism \& transport revenues and tax collections due to low business activities proved to be fatal for the fiscal sector of the economy. Calling the pandemic "a perfect storm for South Asia", the World Bank stated that the fiscal deficit of Pakistan to remain at $9.5 \%$ and $8.7 \%$ of GDP for FY20 and FY21, respectively (DAWN, 2020).

Meanwhile, the shutdown of the services sector is another major blow to Pakistan's economy, leading to a high unemployment rate. According to the Asian Development Bank, Pakistan's services sector may lose $\$ 26.96$ million in mild-case scenarios and $\$ 5$ billion in the worst-case scenario (ADB, 2020a). Javed (2020) estimated the loss to the tourism industry, in Pakistan, based on the World Bank projections. It was revealed that tourism will lose around $\$ 163$ million if traveling restrictions prevailed for three months, and the estimates may increase to $\$ 327.2$ million if the travel restrictions are extended to six months. It is concluded that the tourism, transport, and hospitality sectors are in worse conditions, and millions of workers would be unemployed at the end of 2020 due to COVID-19 (Javed, 2020).

In the past, the economy of Pakistan has been derailed many times due to climate, social and political crises. The paper pays special attention to the economic impact of the flood (2010) and earthquake (2005), which will provide a policy basis for the pandemic. Floods have negatively impacted the economy of Pakistan. Sardar et al. (2016) took two indicators of floodrelated hazards: affected property and monetary damages. By estimation, the authors find that a $1 \%$ increase in the affected population causes a $0.032 \%$ decrease in GDP, and a $1 \%$ direct damage to the property causes a $0.038 \%$ decrease in GDP. Moreover, Pakistan is labeled as a disaster-prone nation due to its geographical location (Shahzad, 2014). Natural disasters like earthquakes are economic growth barriers and cause loss of human capital and infrastructural damage. Developing countries (e.g., Pakistan) and small economies are much more vulnerable to macroeconomic shocks and indirect consequences of natural disasters (Loayza et al., 2012).

The paper discusses the economic impacts of natural disasters in Pakistan and considers the government policies aimed at addressing the consequences of earthquakes and floods in the country. The COVID-19 outbreak is also viewed as a natural disaster, which has a direct and indirect impact on the economy. The paper provides a framework by analyzing the previous disaster management policy that can help Pakistan dig out the policy to encounter economic impacts caused by the coronavirus crisis.

The rest of the paper is structured as, following introduction, research methodology which describes the way the study is conducted in section 2, descriptive analysis which is further divided into four sub-sections in section 3 , policy implications for economic recovery based on the policies devised by the Government of Pakistan in previous natural disasters in section 4 and the last section concludes the study.

\section{METHODOLOGY}

The study uses the descriptive analysis for examining the impact of COVID-19 and previous economic instabilities due to floods, earthquakes on Pakistan's economy. The secondary data is used in the study, and the analysis are extracted from the World Bank, Asian Development Bank, economic reports by the Government of Pakistan, and a few scholarly proceedings. For this purpose, not only existing literature and statistical reports are carefully analyzed, but also national and international natural hazards reports are also reviewed to study the impacts of natural disasters on the economy of Pakistan. The policy of Pakistan's government to respond to natural disasters and its outcomes are also analyzed.

\section{DESCRIPTIVE ANALYSIS}

\section{A Brief History of Natural Disasters in Pakistan}

In the past 15 years, Pakistan has faced multiple natural disasters which have its population and economic stability. The land of Pakistan is prone to floods. The poor management plans paved the way for more floods in the coming years. Table 1 shows that Pakistan has faced around 7 small- and largescale floods from 2007 to 2015 . These consecutive floods had caused a great deal of damage to the economy of Pakistan. Thousands of people were left homeless and their livelihoods were destroyed. The loss of human and physical capital, businesses, and infrastructure destabilized the economy in such a way that Pakistan has never seen a way back to its previous economic pace.

The earthquake and flood in 2005 and 2010, respectively, had a devastating impact on Pakistan's economy. In 2005, an earthquake of 7.6 magnitude struck Pakistan: it killed thousands of people and left millions homeless. The earthquake was one of the worst natural disasters in terms of intensity, shallowness, and destruction in Pakistan. The flood in 2010 affected the country in a more or less similar way. It affected around 20 million people and left thousands of them homeless. The flood caused damage of billions of dollars by destroying infrastructure, assets, agriculture, and residential land. In addition to this damage, there are economic losses: resources are put on recovery efforts resulting in reduced work hours and economic activities. 
Table 1. Natural Calamities in Pakistan (2007-2015).

\begin{tabular}{lllll}
\hline Year & Types of disaster & Causalities & Population affected & Houses destroyed \\
\hline 2007 & Flood & 443 & $2.5 \mathrm{M}$ & 71,486 \\
2008 & Earthquake Balochistan & 164 & - & 9761 \\
2009 & Flood & 80 & $255.7 \mathrm{M}$ & 17,172 \\
2010 & Attabad landslide & 20 & $12.95 \mathrm{M}$ & 457 \\
2010 & Flood & 1,985 & $20 \mathrm{M}$ & 16,02765 \\
2011 & Flood & 520 & $9.3 \mathrm{M}$ & 1604406 \\
2012 & Flood & 571 & $4.8 \mathrm{M}$ & 636438 \\
2013 & Flood & 333 & $1,489.1 \mathrm{M}$ & 79943 \\
2013 & Earthquake Mashkhel & 14 & - & 2250 \\
2013 & Earthquake Awaran & 386 & - & 46756 \\
2014 & Flood & 367 & $2.5 \mathrm{M}$ & 129880 \\
\hline
\end{tabular}

Earthquake (2005): Economic Impact and Government Policy Response

Earthquakes have direct and indirect effects on the economy. The major losses are due to the indirect damages caused by an earthquake. The extent of damage depends on the strength of the infrastructure. In highly populated areas, indirect loss can be greater due to the concentration of buildings. The physical destruction due to earthquakes is a major concern. Due to the collapse of buildings and road maps, the supply chain is affected in specific areas which ultimately have an impact on GDP. This causes an increase in unemployment in the sectors which are not directly affected by the earthquake. Earthquakes cause direct and indirect loss to human capital stock and flow which further leads to destabilization of the environment (Hamdani \& Shah, 2005). The earthquake of 2005, Pakistan, brought great damage to the infrastructure. The damages can be divided into three categories: Direct damage, indirect damage, and reconstruction costs. Reconstructions costs are also considered part of damages because these costs are to be borne by the government or people which could otherwise be spent on other development or welfare programs.

Direct Damage: Table 2 presents the preliminary estimates of the direct damage, which amount to Rs 135.1 billion. Among direct damages, private housing is the largest component, followed by transportation sector. The third largest component is the education sector. Similarly, agriculture, livestock, industrial and services sectors were also in great damage. The estimated figures for the damage to each sector are presented in Table 2.

Indirect Damage: In addition to the direct damages, there was a huge number of indirect damages and losses incurred by different sectors. Table 2 shows that indirect losses resulting from direct damages are Rs. 34.2 billion. The industry and services sector faced the highest indirect loss of Rs. 8.4 billion, particularly due to loss of human capital, breakdown of supply chain and damage to infrastructure. It is followed by private housing, agriculture and livestock, education, and transport sectors. Table 2 presents the estimates of the indirect damages that happened to each sector.

Reconstruction Cost: The total cost of reconstruction is estimated to be around Rs. 208 billion as shown in Table 2. This is divided into three sectors that include social \& physical infrastructure, and economic sector. The largest reconstruction cost was allocated to social sector which was around Rs. 151.468 billion. For reconstruction initiatives, special attention is paid to private housing because this sector was damaged badly in the earthquake. In the same way, Rs. 29.5 billion is allocated to the physical infrastructure as a part of reconstruction cost. The share of economic sector in reconstruction cost is around Rs. 27 billion which is divided into agriculture \& livestock and industrial sector. The detailed reconstruction cost of each sub-sector for all three sectors is given in Table 2.

Table 2. Estimated damage and cost of earthquake (2005) in Pakistan.

\begin{tabular}{llll}
\hline Sector & $\begin{array}{l}\text { Direct damage } \\
\text { (Rs. Million) }\end{array}$ & $\begin{array}{l}\text { Indirect losses } \\
\text { (Rs. Million) }\end{array}$ & $\begin{array}{l}\text { Reconstruction costs } \\
\text { (Rs. Million) }\end{array}$ \\
\hline $\begin{array}{l}\text { Social Infrastructure } \\
\text { Private Housing }\end{array}$ & 61200 & 7218 & 92160 \\
Health & 7114 & 1378 & 18012 \\
Education & 19920 & 4133 & 28057 \\
Environment & 12 & - & 8985 \\
Public Administration & 2971 & 687 & 4254 \\
\hline Physical Infrastructure & & & 24699 \\
Transport & 20,165 & 4061 & 1900 \\
Water supply \& Sanitation & 1,165 & - & 623 \\
Irrigation & 324 & - & 2377 \\
Energy, power and fuel & 744 & 1,561 & 17846 \\
Economic Sector & & & 9178 \\
Agriculture and livestock & 12,933 & 6,770 & 208,091 \\
Industry Service & 8578 & 8379 & 34187 \\
Total & 135,146 & . &
\end{tabular}




\section{Government Policy Response}

The United Nations Office for Coordination of Humanitarian Affairs presented a comprehensive report on the early recovery framework and the key initiatives taken by Pakistan to combat the socio-economic damages of the earthquake (UN, 2005). The Government founded the Earthquake Reconstruction and Rehabilitation Authority (ERRA) that was concerned with managing the reconstruction process. The Prime Minister of Pakistan announced, on October 17, 2005, a 12 Point Plan for Relief, Recovery, and Reconstruction. In addition, the government presented a National Plan of Action, to combat the challenges posed by the earthquakes. The UN report also praised the role of government, army, civil society, and NonGovernmental Organizations. According to this report, the UN Flash Appeal also requested $\$ 550$ million for priority humanitarian operations over six months.

The Asian Development Bank and the Government of Pakistan made collective efforts to analyze the damages and layout the medium to longer-term recovery plans. The results were published in a report titled Damage and Needs Assessment (WB \& ADB, 2005). The recovery plans consisted of guiding principles for planning and implementing activities. These included: Rapid rebuilding of people's livelihoods, secure development gains and progress in poverty reduction and focus on the most vulnerable and socially disadvantaged groups. The World Bank documented the efforts of Pakistan to rebuild the infrastructure in its case study of Disaster Recovery Framework Guide (WB, 2015). The report says, around $\$ 6.2$ billion were allocated to finance the reconstruction process. The ERRA laid out the plans with the teams of engineers and NGOs to devise a framework for the efficient construction and allotment of houses to the affected people.

On the contrary, Khan (2006) indicated that Pakistan was unprepared and lacked organization to handle recovery operations at such a large scale. The ERRA was established after the disaster and it took time to get stimulated and organize the matters. Zaidi (2006) also criticizes that there was a lack of preparedness by the government, and its response was not immediate and reflected many loopholes and wrongdoings. Many victims could not get assistance, and the shelters that they were provided were insufficient to combat the cold winter. The monetary compensation paid to them was not enough either. The government and armed forces lacked cargo, helicopters, and relief equipment, which caused a delay in rescue operations. Poor management, lack of transparency, inadequate planning were the major problems in the way of rehabilitation and reconstruction process (ICG, 2006).

\section{Flood in Pakistan (2010): Economic Impact and Government Policy Response}

Floods can also damage the structure of society by threatening the life, health, property, infrastructure, and livelihood of people. Human beings started living near rivers to get food and fertile lands thousands of years ago. As a result, socioeconomic activities and population growth started growing exponentially over time. Frequent rains and sudden meltdown of snow causes floods. Floods can have both damaging and beneficial impacts depending upon the characteristics of the riverine system. It has always been difficult to quantify these losses or benefits. In some parts, it may bring water for domestic and industrial use and bring nutrients rich water for irrigation.

In the short run, floods reduce economic activities, damage production facilities, and increase the burden on the municipal budget. A shortfall in tax collection may also arise due to a halt in economic activities (Svetlana et al., 2015). On the contrary, floods can have positive impacts on economic growth in the long run, because the government can replace the old technology, and more investment may come in form of relief funds, aids and donations that can be used to build infrastructure and support the economy.

The flood of 2010 in Pakistan caused catastrophic destruction which was followed by a series of other floods in 2011, 2012, 2013, and 2014. Ul Hasan and Zaidi (2012) demonstrated that about $68 \%$ population was living in rural areas at that time, having inadequate access to suitable sustenance. The author further provided the figures to show the percentages of damages happened to different sectors, as demonstrated in Figure 2.

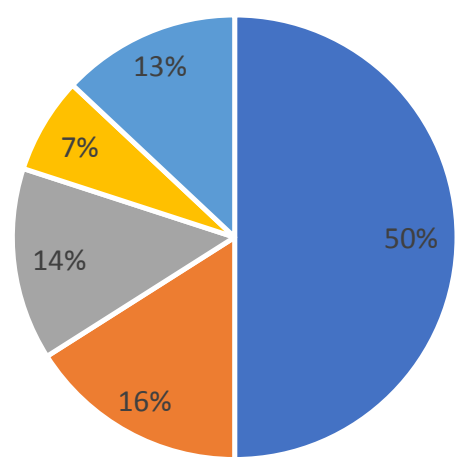

Figure 2. Percentage damages by sector in 2010's flood. Source: Ul Hasan and Zaidi (2012).

Figure 2 shows that the agriculture sector, which is the backbone of the rural economy, is the worst hit sector in this flood resulting in loss of livelihood and increase in unemployment in agriculture related economy. Table 3 presents another set of figures that shows the district-vise impact of the flood. The intensity of the flood can be imagined by the fact that it affected 29 districts hovering over the area of more than 10,000 square kilometers. It affected around 20 
million people in the area damaged by it. The ADB prepared a report, titled Preliminary Damage and Needs Assessment, with the help of Pakistani authorities to estimate the damages, losses and the policies to overcome the flood crisis (WB, 2010). The report showed that the flood affected land also constituted a large amount of infrastructure, irrigation area, and hub of economic activities, and the damages caused by floods resulted in a cost of more than $\$ 10$ billion. Table 4 provides a detailed breakdown of damages and costs. The most affected sector was agriculture and livestock which claimed damage of more than $\$ 5$ billion, followed by the housing sector totaling $\$ 1.59$ billion, communication sector equaling $\$ 1.33$ billion, and the financial sector i.e., banks, ATMs, claiming a damage of $\$ 783$ million collectively. Moreover, health facilities, irrigation lands, communication sector, and energy sector were also in colossal damage by floods.

Table 3. District-wise impact of the flood (2020).

\begin{tabular}{ll}
\hline Total number of affected districts & $78(24 \mathrm{KPK}, 11$ Punjab, 17 Sindh, 12 Balochistan, $7 \mathrm{AJK}, 7 \mathrm{~Gb})$ \\
\hline Most affected districts & 29 \\
Area affected & $10,000+$ sq. kilometer \\
Population affected & 20 million \\
\hline
\end{tabular}

Source: Asian Development Bank (WB, 2010).

Table 4. Estimate of total damage and cost by sector.

\begin{tabular}{lll}
\hline Sector & Damage & Cost (\$) \\
\hline Houses & 1.6 million & \$1.588 billion \\
Energy & 92 plants, 32 grids, $32000 \mathrm{~km}$ & 309 million \\
Agriculture and livestock & 2.1 -million-hectare agricultural land, 0.3 million large & 5.1 billion \\
& and 1.2 million small animals & \\
Private sector & 146 industries, 0.1 million hotels/ shops & 109 million \\
Financial sector & 90 banks, 10 ATMs & 674 million \\
Health sector & 485 health facilities & 50 million \\
Government \& environment & 1457 structure & 82 million \\
Education & 10192 education centers & 311 million \\
Communication & 23831 km & 1.328 billion \\
Water and sanitation & 6673 schemes & 109 million \\
Irrigation & - & 278 million \\
Total & - & 10.056 billion \\
\hline
\end{tabular}

Source: Asian Development Bank (WB, 2010).

\section{Government Policy Response}

The Preliminary Damage and Need Assessment report prepared by ADB and the Government of Pakistan reflects the national and international response in the wake of flood in 2010. The federal and provincial governments mobilized the state institutions (e.g., National Disaster Management Authority-NDMA), assisted by the Army and UN agencies. Army troops, helicopters and boats were mobilized to undertake the rescue operations and provide relief supplies to the affected people. Moreover, an emergency flood relief call center was established.

Much of the emergency relief was provided in the form of clean water, food, kitchen sets and shelter items, sanitation kits and hygiene supplies, medical supplies, mobile and basic health care units. The most prominent feature of the response was the cash transfer mechanism through "Watan card". The Government of Pakistan in collaboration with NADRA distributed around 977,570 Watan Cards (PKR. 20,000 per family) throughout the country (NDMA, 2011). The Watan Card scheme benefited around 3.9 million people of the flood affectees crippled in dire support of relief (NADRA, 2010). Pakistan received US\$ 171 million from the UN under Rapid Response Plan in April 2012 and further $\$ 439$ million support was in line to continue the recovery strategy (MOF, 2011). The international community responded immediately to the Prime Minister's appeal and assisted Pakistan in the form of remittances.
House (2012) used The Global Humanitarian Indicator Tool (GHIT) to assess the quality of a number of emergency responses to the 2010's flood. The author found that Pakistan partially met most of the goals that are set by GHIT, and only few goals were met fully. Pakistan was given a rating of 19 out of 30 points. The most notable quality standard was the measure to address the dignity and protection issues, which the author found to be partially met given certain security risks like economic inequality, infrastructure degradation and civil unrest.

The most severely hit community was 'common man', who became indulged in poverty, which increased as the economic complications became clear with time (Bhatti et al., 2011). A six month recovery analysis, after the disaster, shows that majority of the population had not recovered their previous standard of living or access to services, and the rural population was amongst the slowest to recover (Kirsch et al., 2012).

According to Ali (2013), Pakistan faces several management, institutional and policy problems that affect the government's response towards natural disasters. Particularly talking about the 2010 flood, the author noted that there was a lack of an appropriate flood policy, comprehensive laws, and adequate flood-control infrastructure and scientific knowledge. Deen (2015) indicated that the 2010 floods exposed major policy 
and implementation gaps in flood and disaster management and revealed the disconnect between the local, provincial, and federal governments. The other criticisms came for the delay in setting the institutions in motion to combat the crisis (Wasim, 2015). There are many institutions that become involved when disasters occur, but it results in lack of coordination, poor anticipation of intensity and operational level issues. On the whole, despite many operational difficulties and financial constraints, the government's emergency planning has been more responsive to the needs of the floodplain populations (Ali, 2013).

\section{COVID-19 in Pakistan: Economic Impact and Government Policy Response}

COVID-19 has brought unprecedented changes in the social and economic structure of the world. Governments around the world came up with the idea of a nation-wide lockdown to reducing social activities to the minimum. World Health Organizations issued day to day statements and precautionary measures to avoid the spread of disease. The asymptomatic and explosive nature of the disease brought panic to the social and economic activities. The uncertainty prevailed in stock markets around the globe. Governments announced relief funds, tax relaxation, and public welfare policies. It is observed that the announcement of such policies had a positive impact on stock markets in many countries, while the number of cases and social distancing policies were negatively impacting the stock markets (Ashraf, 2020).

After COVID-19, Pakistan Institute of Development Economics (PIDE) projected a job loss of more than 18 million people in the country (Subohi, 2020). This rising unemployment would create multiple financial, social, and psychological problems among the people. Figure 3 presents some of the macrotrends of Pakistan for the past two decades. It is quite obvious that GDP growth rate was catching up before 2019, while unemployment rate and inflation rate were showing a downward trend at a slow pace. However, COVID-19 turned the tables around with most of the economic activities stopped around the country, the unemployment rate started gearing up and GDP rate fell to its lowest value in 20 years. When the industries could not meet the demand of commodities and the global trade halted, the rise in the prices of food and other necessities gave rise to high inflation rate which was further backed by the devaluation in Pakistani currency.

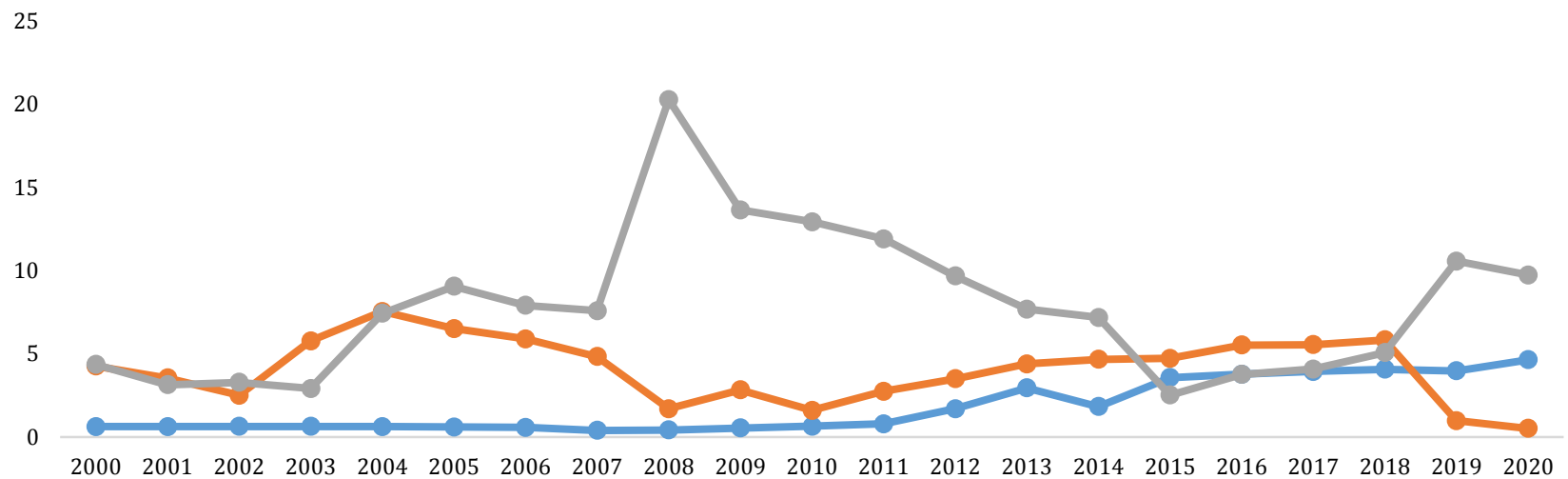

$\longrightarrow$ Unemployment rate $\longrightarrow$ GDP rrowth rate $\rightleftharpoons$ Inflation rate

Figure 3. Macroeconomic Trends of Pakistan (2000-2020).

Source: Asian Development Bank (ADB, 2021).

The coronavirus crisis affected all the economics of the world. In this era of "global village", countries have developed strong economic linkages, and economic crisis in one country impact other countries either directly or indirectly. Pakistan is a big exporter of agriculture and industrial raw material. These sectors were most affected by the COVID-19 crisis due to a decline in supply and demand, as well as the supply chain disruption across the globe. So, the economies were contracted due to a decrease in consumer demand and a shortfall in output. Asian Development Bank published a brief report of the estimated loss of the corona crisis on major sectors of Pakistan's economy, in which estimated losses to Pakistan's economy under best- \& worst-case scenario due to COVID-19 are given. Table 5 provides the monetary loss to different sectors as reported by and Asian Development Bank. Best-case scenario: It is obvious from Table 5 that the agriculture \& mining sector is the worst hit in best case scenario with an estimated loss of $\$ 16.23$ million, which is followed by trade and services sector (\$5.54 million), manufacturing sector ( $\$ 3.6$ million), transport sector $(\$ 0.92$ million), and hostels \& restaurants sector ( $\$ 0.67$ million).

Worst-case scenario: Table 5 shows that business, trade, and services sector is the worst hit under worst-case scenario with an estimated loss of $\$ 1.94$ billion, followed by agriculture and mining sector ( $\$ 1.5$ billion), manufacturing sector $(\$ 671$ million), transport sector (\$565.6 million), and hotels \& restaurants sector ( $\$ 253.7$ million).

To conclude, in the best-case scenario, an estimated loss of $\$ 26.96$ million is expected while in a worst-case scenario, an estimated loss of $\$ 5$ billion is expected to major sectors of the economy. State Bank of Pakistan presented a report concerning the growth incurred by the travel and workers' remittances sector is presented for the FY $19 \& 20$ (Table 6). 
An influential growth in travel services and workers' remittances is observed from FY 19 to FY 20, but these two sectors are affected by COVID-19 crisis due to the travel restrictions and loss of workers' remittances owing to increase in unemployment.

Pasha and Kardar (2020) projected growth rates of macroeconomic variables in fourth quarter of FY 2019, 20 (Table 7). The data is projected for two different scenarios; scenario 1 captures the effects of less severe shocks and scenario 2 captures the effects of more severe shocks. It can be observed that there is a significant decline in private consumption expenditures which can affect the living standard of the people in coming months. The public consumption expenditure may increase to $12 \%$ or $8 \%$ under scenario I and scenario II, respectively. Another sharp decline can be seen in case exports of goods and services. However, imports of goods and services increase to $5 \%$ probably due to a decline in import prices, while a $3 \%$ decline is observed in scenario-II. The net taxes and GDP factor cost is projected to decrease from 5 to $10 \%$. The rate of inflation can also significantly increase from 10 to $16 \%$.

Table 5. Estimated loss to Pakistan's economy under best \& worst case.

\begin{tabular}{llll}
\hline Best-case scenario & Estimated loss & Worst-case scenario & Estimated loss \\
\hline $\begin{array}{l}\text { Agriculture and mining sector } \\
\text { Business trade, personal and }\end{array}$ & $\$ 16.23$ million & Agriculture and mining sector & $\$ 1.5$ billion \\
public services & $\$ 5.54$ million & Business trade, personal and & $\$ 1.94$ billion \\
Light and heavy manufacturing & $\$ 3.6$ million & Lublic services & \\
Transport services & $\$ 0.92$ million & Transport services & $\$ 565.6$ million \\
Hotels and restaurants & $\$ 0.67$ million & Hotels and restaurants & $\$ 253.7$ million \\
Total & $\$ 26.96$ million & Total & $\$ 5$ billion \\
\hline
\end{tabular}

Source: Asian Development Bank (ADB, 2020a) .

The Asian Development Bank, in its 2020, outlook report forecasted the GDP of Pakistan (Figure 3). In April 2020, ADB has forecasted that Pakistan would grow to $2.6 \%$ in 2020 and $3.2 \%$ in 2021. The ADB later updated its GDP forecast due to the severe economic impact of COVID-19 erasing the economic gains in the first two quarters of 2020. Under COVID-19, it was foretold that GDP would grow at a rate of $-0.4 \%$ in 2020 and would recover to $2 \%$ in 2021.

Table 6. Travel and worker's remittances (Million \$).

\begin{tabular}{lll}
\hline Description & FY 20 & FY 19 \\
\hline Travel services & 320.3 & 247.1 \\
Workers' remittances & $23,132.3$ & $21,739.4$ \\
\hline
\end{tabular}

Source: State Bank of Pakistan (SBP, 2020).

Table 7. Projected Growth Rates of Macroeconomic Variables in 4th Quarter of FY 19-20

\begin{tabular}{lll}
\hline Variables & Scenario I & Scenario II \\
\hline Private Consumption Expenditure & -4.4 & -8.2 \\
Public Consumption Expenditure & 12 & 8 \\
Public Investment & -11.7 & -27 \\
Private Investment & 15 & 10 \\
Exports of Goods and Services & -6.8 & -15 \\
Imports of Goods and Services & 5.2 & -2.6 \\
Net Taxes & -5 & -9.5 \\
GDP factor cost & -4.6 & -9.5 \\
Rate of Inflation & 9.6 & 16.1 \\
\hline
\end{tabular}
Source: Pasha and Kardar (2020).

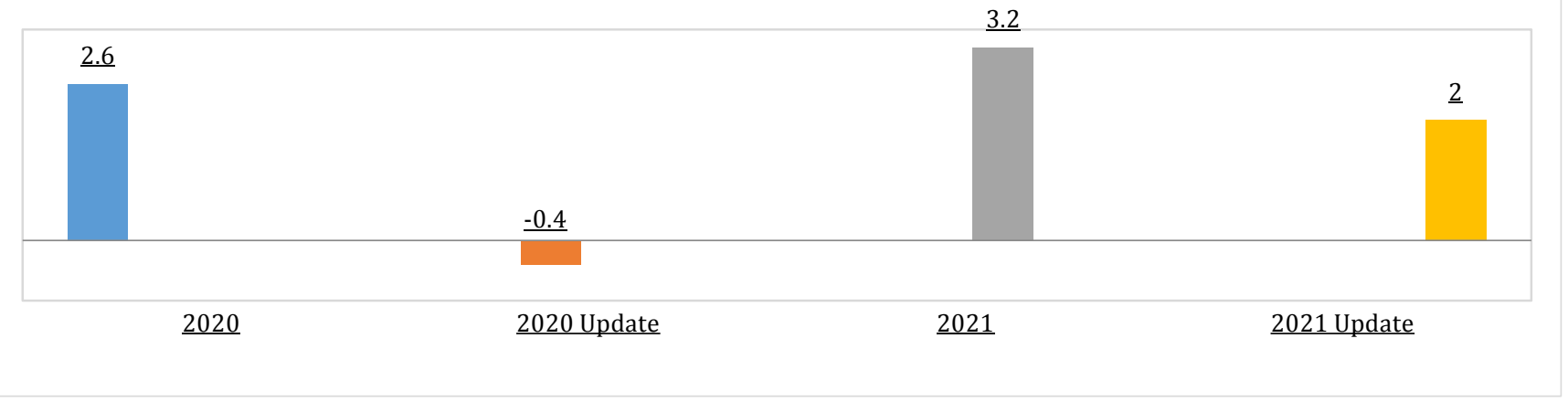

Figure 4. Pakistan GDP forecast.

Source: Asian Development Bank (ADB, 2020b). 


\section{Government Policy Response}

COVID-19 is reshaping the world's social, cultural, political, and economic matters. As a result, different economies are using diverse techniques to combat this lethal virus. Ashraf (2020) collected daily data of 77 countries from January 22 to April 17, 2020 and it is figured out that government intervention on social distancing has a negative impact on stock markets due to the adverse effects on economic activity. The Government of Pakistan was hesitant to put lockdown in the country, due to the financial challenges and deteriorated economic situation. The lockdown began in Sindh province where the earliest cases were reported. After the cases spread to other provinces, the federal government decided to put a nation-wide lockdown. Government imposed the lockdown in a series of small steps: at first, highly crowded places like academic institutions were closed. When the situation became worse, restaurants and public transport were are also included in the lockdown. The nation-wide lockdown was imposed on April 1, 2020 which was extended twice till May 6, 2020 (Raza, 2020). People became insecure after the imposition of lockdown because, all the means of their livelihood were frozen. It is reported that most of the suicides occurred, in Pakistan, due to the fear of economic recession, not from the COVID-19 (Mamun \& Ullah, 2020).

Prime minister Imran Khan initiated a corona relief 'Tiger Force' to spread awareness about the COVID-19. The registration of this force was started on March 31, 2020, and thousands of youngsters participated in the campaign. The purpose of this force was to distribute food and also spread awareness about COVID-19 among the people. Government of Pakistan also initiated the EHSAS program to provide financial assistance to the needy. On April 01, 2020, Prime Minister launched this anti-poverty scheme having a budget of Rs.203 billion (12000 per family), covering around 15 million families (GOP, 2020). On macroeconomic level, government adopted expansionary fiscal policy such as reduced taxation and increased government expenditures (Ashfaq \& Bashir, 2020). On June 13, 2020, the government converted countrywide lockdown into 'smart lockdown'. In this particular lockdown, all other activities were banned except the labor force was allowed to go out for earning (Rukh et al., 2020). The smart lockdown strategy and the financial assistance form the government of Pakistan acted as a buffer against the dire economic consequences of COVID-19 on the poor people of the economy. Although most the countries imposed a fulllockdown, but smart lockdown was appreciated by media and many countries around the world (APP, 2020; News, 2020).

\section{Policy Implications}

COVID-19 has created a situation of emergency in Pakistan, as well as the whole world. For Pakistan, the COVID-19 as a natural disaster is different from other natural disasters (e.g., floods and earthquakes) in a way that the COVID-19 has not disrupted the socio-economic system of the Pakistan alone, but the whole world. This emphasizes that the global community needs to act together in order to retain the precorona life. As per the demand of the situation, Pakistan needs to take actions by inculcating the national and international institutions which are concerned with health and economy.
Following are the policy measures that Pakistan can act upon to revive its previous economic pace. Although the measures are advised by considering the previous disaster policy of Pakistan, but some other recommendations are necessary to be added because COVID-19 is a global phenomenon as compared to other natural disasters in Pakistan which are of local nature. It is also a chance for Pakistan to address loopholes in its previous policy of managing disasters.

The situation like COVID-19 require an active role of the government in regulating the market in terms of prices and provision of life sustaining commodities. The government should help in terms of direct cash transfer, like those of Watan Cards, to needy households for food support and basic commodities of life. Financial support can also be given in form of subsidies on necessities. Evidence shows conditional cash transfers (Rawlings \& Rubio, 2005) especially during natural disasters had a positive impacts on social and economic sectors of the economy (Mansur et al., 2018).

Unlike other natural disasters, COVID-19 has put more pressure on health sector of the economy. Floods and earthquakes destroy the infrastructure, but COVID-19 has created shortage of healthcare workers in the country. Government can address the decline in public investment by spending more in health sector. This will not only generate employment but will help to meet the demands of emergency. Government spending in health sector will help to react more effectively to pandemic like situation. According to Bivens (2012), increase in public investment also boosts the GDP and the productivity of the private-sector which supports the economy in disaster like situation.

As indicated by Deen (2015) and WCDR (2005), Pakistan lacks a culture of research and scientific knowledge, which underestimates the recovery policies of the government under disaster situations and resultantly Pakistan faces harsh economic consequences. Government needs to spend more on Research and development (R\&D) and develop a culture of scientific knowledge. This will help in pre-planning and minimizing the loss of economic resources.

Pakistan needs to depoliticize its economic, social and other administrative institutions. Political parties in Pakistan often use the pandemic like situation to build the pressure on ruling party, which affects the performance of the recovery strategies. Moreover, the lack of coordination between institutions also affects the execution of the policies as seen in case of flood (2010) and earthquake (2005). The political parties are required to develop a 'common agenda' and make institutional reforms that are acceptable by all. This will help to react more fiercely to emergency situation and avoid the grave economic concerns of natural disasters.

Pakistan needs to reevaluate its disasters management structure. For effective disaster preparedness, there is a need to take drastic measures in improving the local capacity and the knowledge-base of the plans. As Bussell and Asim (2017) highlighted that Pakistan should not rely on recovery strategies only, rather equal importance should be given to the disaster preparedness and risk reduction. Disaster preparedness will help to timely respond and minimize the damage to the economy. The government, is this regard, can revolutionize its technology and IT industry. With fast 
communication technology, it would be much easier to transfer important data from one place to another. This will increase the response rate and help to contain the emergency situation in a much less time.

COVID-19 has created the most urgent need for global cooperation. As the word 'pandemic', also signifies globularity in nature so all countries should cooperate to combat the disease. Pakistan needs to strengthen its regional and crossregional cooperation to combat the disease through different platforms. Underdeveloped countries like Pakistan and Iran are already struggling hard to maintain their health and financial stability. The national and international community should cooperate and make a joint effort to support the countries that have weak health and economic system.

\section{CONCLUSIONS}

COVID-19 also had a profound impact on the economy of Pakistan, in terms of increase in unemployment, inflation, and a decline in economic growth. While the policies of government are at full swing, there are still loopholes in managing the disaster which is accustomed as evident from the management of previous disasters. The study finds that Government of Pakistan fails to get full output of its recovery plans due to lack of preparedness \& coordination, lack of understanding, absence of central authority, insufficient knowledge \& planning, and other institutional or management issues. It is also found that disaster management policies of Pakistan require pre-planning, timely response and effective coordination between different institutions. The study finally concludes that government needs to intervene in the market to regulate prices, give direct cash to people, invest in R\&D, and strengthen ties with neighboring economies to come out of COVID-19 crisis.

\section{Acknowledgment}

The authors would like to acknowledge the School of Economics, University of the Punjab, Lahore, Pakistan.

\section{Authors Contribution}

All authors contributed equally in designing, data collection, assimilation, and writing of this manuscript, and the final version was read and approved by all authors.

\section{Conflict of Interest}

The authors declare no conflict of interest.

\section{REFERENCES}

Abid, K., Bari, Y.A., Younas, M., Tahir Javaid, S., Imran, A., 2020. Progress of COVID-19 epidemic in Pakistan. Asia Pacific J. Public Heal. 32, 154-156.

ADB, 2021. Economic Indicators for Pakistan. Asian Development Bank

ADB, 2020a. The economic impact of the COVID-19 outbreak on developing Asia, ADB Briefs. Asian Development Bank.

ADB, 2020b. Pakistan Could See 2021 Economic recovery if COVID-19 subsides, structural reforms resume - ADB Report.
Ali, A., 2013. Indus basin floods mechanisms, impacts, and management. ADB (Asian Development Bank), Mandaluyong City.

APP, 2020. Prime minister's 'smart lockdown' lauded globally. Express Trib.

Ashfaq, M., Bashir, M., 2020. Pakistan: Making a "COVID budget" in a struggling economy. J. Public Budgeting, Account. Financ. Manag. 33,69-77.

Ashraf, B.N., 2020. Economic impact of government interventions during the COVID-19 pandemic: International evidence from financial markets. J. Behav. Exp. Financ. 27, 100371. doi: 10.1016/j.jbef.2020.100371.

Badshah, S.L., Ullah, A., Badshah, S.H., Ahmad, I., 2020. Spread of Novel Coronavirus by returning pilgrims from Iran to Pakistan. J. Travel Med. 27, 1-3.

Baldwin, R., Di Mauro, B.W., 2020. Economics in the time of COVID-19: A new eBook. VOX CEPR Policy Portal 2-3.

BBC, 2020. Global coronavirus cases pass 50 million - BBC News. BBC.

Bhatti, N., Jamali, M.B., Ghumro, I.A., Shaikh, F.M., 2011. Supreme flood and its impact on poverty in rural Sindh. Aust. J. Bus. Manag. Res. 5, 50-62.

Bivens, J., 2012. Public investment: The next 'new thing'for powering economic growth. Econ. Policy Institute, Brief. Pap. 338.

Bussell, J., Asim, F., 2017. The political economy of disaster preparedness and risk reduction in Pakistan. CEPSA Res. Br. 5.

DAWN, 2020. Pandemic a "perfect storm" for South Asia, World Bank says. DAWN.

Deen, S., 2015. Pakistan 2010 floods. Policy gaps in disaster preparedness and response. Int. J. disaster risk Reduct. 12, 341-349.

Fernandes, N., 2020. Economic effects of coronavirus outbreak (COVID-19) on the world economy. IESE Business School Working Paper No. WP-1240-E, dx.doi.org/10.2139/ssrn.3557504.

GOP, 2021. Covid-19 health advisory platform by ministry of national health services regulations and coordination, Islamabad, Pakistan.

GOP, 2020. Ehsaas. Poverty alleviation and social safety division. Government of Pakistan, Pakistan.

Gruszczynski, L., 2020. The COVID-19 pandemic and international trade: Temporary turbulence or paradigm shift? Eur. J. Risk Regul. 11, 337-342.

Haider, M., 2020. Pakistan's GDP may contract by more than $4 \%$ due to trade disruptions alone. GEO.

Hamdani, N.H., Shah, S.A.H., 2005. Earthquake 2005: Some implications for environment and human capital. Munich Personal RePEc Archive Paper No. 9519.

Harari, Y.N., 2014. Sapiens: A brief history of humankind. Publish in agreement with The Deborah Harris Agency the Grayhawk Agency.

House, S., 2012. Effectiveness review: Pakistan flood response 2011/12. Oxfam.

ICG, 2006. Political Impact of the earthquake | Crisis Group. Crisis Group. 
Iqbal, N., Javid, M., 2020. PIDE-COVID-Bulletin-20. Accesed from; https://pide.org.pk

James, S., Sargent, T.C., 2006. The economic impact of an influenza pandemic. Canada Department of Finance. Work. Pap. 2007-04.

Javed, A., 2020. Impact of COVID-19 on Pakistan's services sector. J. Inovasi Ekonomi. 5, 107-116. 10.22219/jiko.v5i03.12194.

Khan, F.A., 2006. The response to the earthquake in Pakistan. Humanitarian Practice Network. Humanit. Pract. Netw.

Kirsch, T.D., Wadhwani, C., Sauer, L., Doocy, S., Catlett, C., 2012. Impact of the 2010 Pakistan floods on rural and urban populations at six months. PLoS Curr. Disas. 4, 1-7. doi: 10.1371/4fdfb212d2432.

Last, J.M., 2001. A dictionary of epidemiology. Edited by John, M., Last, Rrobert, A., Spasoff, Susan, G.H. Am. J. Epidem. 154(4), 389-389.

Loayza, N. V, Olaberria, E., Rigolini, J., Christiaensen, L., 2012. Natural disasters and growth: Going beyond the averages. World Dev. 40, 1317-1336.

Maliszewska, M., Mattoo, A., Van Der Mensbrugghe, D., 2020. The potential impact of COVID-19 on GDP and trade: A preliminary assessment. World Bank Policy Res. Work. Pap (9211).

Mamun, M.A., Ullah, I., 2020. COVID-19 suicides in Pakistan, dying off not COVID-19 fear but poverty?-The forthcoming economic challenges for a developing country. Brain. Behav. Immun. 87, 163-166.

Mansur, A., Doyle, J., Ivaschenko, 0., 2018. Cash transfers for disaster response: lessons from Tropical Cyclone Winston. Dev. Econ: Agri. Pap. No.67. DOI:10.2139/ssrn.3143459.

MOF, 2011. Flood Impact Assesment, Economic Survey of Pakistan. Ministery of Finance.

Morens, D.M., Folkers, G.K., Fauci, A.S., 2009. What is a pandemic? In: The University of Chicago Press.

NADRA, 2010. Watan Card - NADRA Pakistan.

NDMA, 2011. NDMA National Disaster Management Authority Pakistan.

News, T., 2020. Smart lockdown strategy proved beneficial for businesses: ICCI president. News.

Pasha, H., Kardar, S., 2020. Economic impact of the coronavirus and the relief package. Business Recorder, March 31, viewed 31 March 2020.

PBS, 2015. Compendium on Environment Statistics of Pakistan 2015 | Pakistan Bureau of Statistics.

Phin, N.F., 2011. Living forwards, understanding backwards. Bull. World Health Organ. 89, 541-542.

Rasheed, R., Rizwan, A., Javed, H., Sharif, F., Zaidi, A., 2021. Socio-economic and environmental impacts of COVID-19 pandemic in Pakistan-an integrated analysis. Environ. Sci. Pollut. Res. 28, 19926-19943.

Rawlings, L.B., Rubio, G.M., 2005. Evaluating the impact of conditional cash transfer programs. World Bank Res. Obs. 20, 29-55.

Raza, S.I., 2020. Govt extends lockdown till mid-Ramazan. DAWN.
Rukh, L., Nafees, M., Khan, F., 2020. Evaluation of forcedlockdown partial lockdown and smartlockdown against COVID-19 hazard and related problems: An example from Pakistan. Hum. Soc. Sci. $27,25-25$.

Sardar, A., Javed, S.A., Amir-ud-Din, R., 2016. Natural disasters and economic growth in Pakistan: An enquiry into the floods related hazards' triad. Dep. Environ. Econ. Pakistan Inst. Dev. Econ. Islam. Pakistan, Work. Pap. 10.

Saunders-Hastings, P.R., Krewski, D., 2016. Reviewing the history of pandemic influenza: understanding patterns of emergence and transmission. Pathogens 5, 66. doi.org/10.3390/pathogens5040066.

SBP, 2020. State of the economy, statistical supplement 2019, 20. State Bank of Pakistan.

Sen, Shuvro, Antara, N., Sen, Shusmita, Chowdhury, S., 2020. The apparel workers are in the highest vulnerability due to COVID-19: A study on the Bangladesh, Appar. Ind. Asia Pacific J. Multidiscip. Res. 8, 1-7.

Shahzad, U., 2014. Impact Assessment of natural disasters upon economic growth in Pakistan. 2nd International conference on energy, regional integration and Socioeconomic development 7373, Eco.Mod. Pp. 1-27.

Subohi, A., 2020. A job-killing pandemic. DAWN.

Svetlana, D., Radovan, D., Ján, D., 2015. The economic impact of floods and their importance in different regions of the world with emphasis on Europe. Procedia Econ. Financ. 34, 649-655.

Taubenberger, J.K., Morens, D.M., 2009. Pandemic influenzaincluding a risk assessment of H5N1. Rev. Sci. Tech. 28, 187-202.

Thunström, L., Newbold, S.C., Finnoff, D., Ashworth, M., Shogren, J.F., 2020. The benefits and costs of using social distancing to flatten the curve for COVID-19. J. BenefitCost Anal. 11, 179-195.

Ul Hasan, S.S., Zaidi, S.S.Z., 2012. Flooded economy of Pakistan. J. Dev. Agric. Econ. 4, 331-338.

Umer, S., 2018. A brief history of human evolution: challenging Darwin's claim. Int. J. Anthropol. Ethnol. 2, 1-17.

UN, 2005. Pakistan 2005 earthquake: Early recovery framework. UN System Publications, Islamabad.

Waris, A., Atta, U.K., Ali, M., Asmat, A., Baset, A., 2020. COVID19 outbreak: Current scenario of Pakistan. New Microbes New Infect. 35, 100681. doi: 10.1016/j.nmni.2020.100681.

Wasim, A., 2015. Govt criticised for keeping NDMC dormant Pakistan. DAWN.

WB, 2015. Disaster recovery framework guide. World Bank.

WB, 2010. Pakistan floods 2010 : Preliminary damage and needs assessment project. World Bank. Asian Development Bank. Governmant of Pakistan, Islamabad.

WB, ADB, 2005. Pakistan - 2005 earthquake preliminary damage and needs assessment. World BankAsian Development Bank.

WCDR, A., 2005. Review of disaster management policies and systems in Pakistan. Islamabad, Pakistan. 
WHO, 2020a. Coronavirus disease 2019 (COVID-19): Situation report, 94. World Health Organization.

WHO, 2020b. WHO Coronavirus disease (COVID-19) Dashboard. World Health Organization.
Zaidi, S.H., 2006. Response of Government and society to the October earthquake. Pak. Horizon, 59, 39-54.

Zhang, D., Hu, M., Ji, Q., 2020. Financial markets under the global pandemic of COVID-19. Financ. Res. Lett. 36.

Publisher's note: Science Impact Publishers remain neutral with regard to jurisdictional claims in published maps and institutional affiliations.

(c) (†)

Open Access This article is licensed under a Creative Commons Attribution 4.0 International License, which permits use, sharing, adaptation, distribution and reproduction in any medium or format, as long as you give appropriate credit to the original author(s) and the source, provide a link to the Creative Commons license and indicate if changes were made. The images or other third-party material in this article are included in the article's Creative Commons license, unless indicated otherwise in a credit line to the material. If material is not included in the article's Creative Commons license and your intended use is not permitted by statutory regulation or exceeds the permitted use, you will need to obtain permission directly from the copyright holder. To view a copy of this license, visit https://creativecommons.org/licenses/by/4.0/. 